\title{
Blood transfusions and its rational use in obstetrics
}

\author{
Pushpanjali Malipatil*, V. B. Malipatil
}

Department of Obstetrics \& Gynaecology, Raichur institute of medical sciences, Raichur, Karnataka, India

Received: 22 February 2016

Accepted: 25 February 2016

*Correspondence:

Dr. Pushpanjali Maliapatil,

E-mail: drpushpanjali18@yahoo.in

Copyright: ( ) the author(s), publisher and licensee Medip Academy. This is an open-access article distributed under the terms of the Creative Commons Attribution Non-Commercial License, which permits unrestricted non-commercial use, distribution, and reproduction in any medium, provided the original work is properly cited.

\section{ABSTRACT}

Background: Blood transfusion (BT) during or after delivery is a serious and sometimes a predictable event. This study helps to generate the information and knowledge regarding the various aspects of blood transfusions in obstetrics and its rational use and alternative strategies.

Methods: This is retrospective study of 184 obstetric patients who had 288 blood transfusions during the month of March and April 2014 in the department of obstetrics in an urban tertiary care referral government teaching institute.

Results: During this study period of 2 months from March to April 2014 there were 907 admissions in the labour room and 642 deliveries. Among these, 184 patients received blood transfusions. Numbers of blood transfused were 288. The main indication of blood transfusion was anaemia.

Conclusions: As many as 56\% of pregnant women are anaemic depending on the geographic and socio-economic group studies. Various strategies can be implemented to reduce the anaemia and decrease the number of blood transfusions so that patient will receive the maximum benefit with minimal risks.

Keywords: BT, Hb, Pregnancy, Anaemia

\section{INTRODUCTION}

There are marked physiological changes in the composition of blood in healthy pregnancy. The increase in the total blood volume and haemostatic changes help to combat the hazard of haemorrhage at delivery. There is dramatic increase in plasma volume $(50 \%)$ and increase in red cell mass of $18 \%-25 \%$ depending upon the iron status. These changes cause dilutional decrease in $\mathrm{Hb}$ concentration erroneously called the "physiological anaemia of pregnancy".

Between the age of 20 and 40, a fertile, sexually active woman is potentially capable of giving birth about 12 times in even if she breastfeeds each baby for 1 year. The female is always in precarious iron balance during the reproductive years.

The pathological anaemia in pregnancy is due to iron deficiency. Globally, Over $90 \%$ of anaemia is due to red cell iron deficiency associated with depleted iron stores and deficient intake. Other conditions such as foliate, vitamin $\mathrm{B}_{12}$ and Vitamin $\mathrm{A}$ deficiencies, chronic inflammation, parasitic infections and inherited disorders can all cause anaemia. There is increasing in demand for iron with advancing pregnancy. If women enters pregnancy with depleted iron stores, then the effects of iron deficiency will develop.,

One of the haematological changes in pregnancy is the increase and shift in 2,3-di phosphoglycerate to the right making oxygen readily available to the foetus. Therefore in anaemic mothers, foetal oxygen requirements should not be jeopardised unless the anaemia is severe or the foetus is already compromised by placentation problems.

No important physiological impairment may be noted at $\mathrm{Hb}$ levels as low as 6-8 gm/dl. ${ }^{3}$ The physiological changes after parturition results in reduction in the circulation blood volume, increase in peripheral resistance and physiological concentration. These factors maintain the blood pressure in the phase of loss and further reduce the need for transfusion after delivery. 
The WHO recommends that $\mathrm{Hb}$ concentration should not fall below $11 \mathrm{gm} / \mathrm{dl}$ at any time during pregnancy. ${ }^{4}$ United States report of health and human services ${ }^{5}$ laid down guidelines for use of blood products generally. They are, (a) Acute blood loss of any amount if any clinical evidence of inadequate oxygen carrying capacity (b) $\mathrm{A} \mathrm{Hb}$ of $<7 \mathrm{gm} / \mathrm{dl}$ (Haemotocrit of 0.21 ) if not due to treatable cause (c) Symptomatic anaemia regardless of $\mathrm{Hb}$ level (d) Patients receiving general anaesthesia if their preoperative $\mathrm{Hb}$ is $<7 \mathrm{gm} / \mathrm{dl}$ (e) A major blood letting operation and a $\mathrm{Hb}$ of $<10 \mathrm{gm} / \mathrm{dl}$ (Haematocrict of $<0.30)$. The red cross transfusion services in Victoria Australia has made similar recommendations. ${ }^{6}$

The blood transfusion rate varies from country to country, within the country, within the states, within the hospitals. SANGUIS study ${ }^{7}$ of 43 European hospitals found enormous variability in the percentage of patients transfused red cells among hospitals within same country.

The purpose of this study is to know the indications that lead to blood transfusions and to address the risk benefit ratio of blood transfusions in a variety of clinical situations, and formulate various strategies in an attempt to reduce the blood transfusions.

\section{METHODS}

This was a retrospective study conducted at a tertiary care referral government teaching institute over a period of 2 months (March 2014 and April 2014) in the department of obstetrics. $\mathrm{Hb}$ estimation was done in all patients admitted in pre labour ward, labour ward, postnatal ward (24-48 hours after delivery). Those patients who underwent blood transfusions were analyzed.

\section{RESULTS}

In this study period of 2 months there were 907 admissions and 642 deliveries. Among these, 184 patients received blood transfusions and numbers of blood transfusion were 288. All transfusions were of whole blood except 4 of them who received component therapy. Whole blood was transfused because of non-availability of component therapy (Table 1 ).

Table 1: Statistics of labour room.

\begin{tabular}{|ll|lll|}
\hline Month & No. of admissions & No. of deliveries & $\begin{array}{l}\text { No. of patients who received } \\
\text { blood transfusion }\end{array}$ & $\begin{array}{l}\text { Total no. of blood } \\
\text { transfusion }\end{array}$ \\
\hline March 2014 & 434 & 302 & 85 & 119 \\
\hline April 2014 & 473 & 340 & 99 & 169 \\
\hline Total & 907 & 642 & 184 & 288 \\
\hline
\end{tabular}

Table 2: Haemoglobin status and blood transfusion.

\begin{tabular}{|llll|}
\hline Month & Haemoglobin percentages & \\
\hline & $\leq 7 \mathrm{gm} / \mathrm{dl}$ & $\begin{array}{l}>7 \mathrm{gm} / \mathrm{dl}- \\
\leq 9 \mathrm{gm} / \mathrm{dl}\end{array}$ & $>9 \mathrm{gm} / \mathrm{dl}$ \\
\hline $\begin{array}{l}\text { March } \\
2014(85)\end{array}$ & 29 & 27 & 29 \\
\hline $\begin{array}{l}\text { April 2014 } \\
(99)\end{array}$ & 45 & 40 & 14 \\
\hline $\begin{array}{l}\text { Total no. }= \\
84\end{array}$ & $74(40 \%)$ & $67(36 \%)$ & $43(24 \%)$ \\
\hline
\end{tabular}

The $\mathrm{Hb}$ status in patients who underwent blood transfusions was $\leq 7 \mathrm{gm} / \mathrm{dl}$ in $74(40 \%),>7 \mathrm{gm} / \mathrm{dl}$ to $\leq 9$ $\mathrm{gm} / \mathrm{dl}$ in $67(63 \%)$ and $>9 \mathrm{gm} / \mathrm{dl}$ in 43 (24\%) (Table 2). Among 184 patients who were transfused, 59 (32\%) were primigravida, $56(31 \%)$ were second gravida, $50(27 \%)$ were third gravida and only $19(10 \%)$ were gravida 4 and above (Table 3). 121 (66\%) patients were from rural areas and $63(34 \%)$ were from urban areas (Table 4). Among 184 patients, $66(36 \%)$ of the patients were 22 years old and younger, 62 (34\%) were between 23 and 25 years and $56(20 \%)$ were 26 years and above (Table 5).

Table 3: Parity distribution of blood transfusion.

\begin{tabular}{|lllll|}
\hline & Primigravida & Gravida 2 & Gravida 3 & Gravida 4 and above \\
\hline March 2014 & 29 & 29 & 18 & 9 \\
\hline April 2014 & 30 & 27 & 32 & 10 \\
\hline Total $(484)$ & $59(32 \%)$ & $56(31 \%)$ & $50(27 \%)$ & $19(10 \%)$ \\
\hline
\end{tabular}


Table 4: Area distribution.

\begin{tabular}{|lll|}
\hline & Rural & Urban \\
\hline March 2014 & 64 & 21 \\
\hline April 2014 & 57 & 42 \\
\hline Total (184) & $121(66 \%)$ & $63(34 \%)$ \\
\hline
\end{tabular}

Table 5: Age distribution of blood transfusion.

\begin{tabular}{|llll|}
\hline \multicolumn{4}{|c|}{ Age in years } \\
\hline & $\leq 22$ & $23-25$ & $\geq 26$ \\
\hline $\begin{array}{l}\text { March } \\
2014\end{array}$ & 35 & 25 & 25 \\
\hline April 2014 & 31 & 37 & 31 \\
\hline $\begin{array}{l}\text { Total }( \\
\text { 184) }\end{array}$ & $66(36 \%)$ & $62(34 \%)$ & $56(30 \%)$ \\
\hline
\end{tabular}

Table 6: Interval between deliveries and blood transfusion.

\begin{tabular}{|llll|}
\hline $\begin{array}{l}\text { Last delivery } \\
(125)\end{array}$ & $\begin{array}{l}\leq 2 \\
\text { years }\end{array}$ & $\begin{array}{l}>2 \text { years } \\
\leq 3 \\
\text { years }\end{array}$ & $\begin{array}{l}>3 \\
\text { years }\end{array}$ \\
\hline March & 25 & 21 & 10 \\
\hline April & 30 & 23 & 16 \\
\hline \multirow{2}{*}{ Total (125) } & 55 & 44 & 26 \\
& $(44 \%)$ & $(35 \%)$ & $(21 \%)$ \\
\hline
\end{tabular}

The interval between the last delivery and subsequent pregnancy in 125 multigravidas was 2 years and less in $55(44 \%),>2$ years and $\leq$ to 3 years in $44(35 \%)$ and more than 3 years in $26(21 \%)$ (Table 6$)$. Among total of 184 patients, 118 of them had 1 unit of blood transfusion,
38 patients has 2 units of blood transfusions, 19 patients had 3 units of blood transfusions and 9 patients had 4 and more units of blood transfusions (Table 7).

Table 7: Units of blood transfusion.

\begin{tabular}{|lllll|}
\hline & Units of blood transfused & \\
\hline $\begin{array}{l}\text { No. of } \\
\text { patients } \\
\text { transfused }\end{array}$ & 1 Unit & $\begin{array}{l}2 \\
\text { Units }\end{array}$ & $\begin{array}{l}3 \\
\text { Units }\end{array}$ & $\begin{array}{l}\text { Units } \\
\text { and } \\
\text { more }\end{array}$ \\
\hline March 2014 & 62 & 13 & 9 & 1 \\
\hline April 2014 & 56 & 25 & 10 & 8 \\
\hline Total (288) & 118 & 38 & 19 & 9 \\
\hline
\end{tabular}

The commonest indication of BT was anaemia in 140 (76\%) of patients (Table 8). Anaemia was a direct and indirect indication for BT. Among 140 patients 30 of them had BTs pre labour as they were severely anaemic, some of them symptomatic with complaints of giddiness and easy fatigability and some of them asymptomatic. 58 patients received BT after caesarean section, many of them with moderate anaemia but in view of excessive blood loss during surgery. 52 of the patients received BT during labour and within 48 hours postpartum. Other common indications for BT were PPH in 25 (14\%), APH $11(6 \%)$, abortions $4(2 \%)$, molar pregnancy $2(1 \%)$ and ectopic pregnancy $2(1 \%)$. There 20 still births in this study due to causes like abruptio placenta, pregnancy induced hypertension and obstructed and abnormal labour.

Table 8: Indications for blood transfusions.

\begin{tabular}{|lllll|}
\hline $\begin{array}{l}\text { Indications for blood } \\
\text { transfusion }\end{array}$ & March 2014 & April 2014 & Total (184) \\
\hline \multirow{3}{*}{ Anaemia 140 (76\%) } & Pre labour & 11 & 19 & 30 \\
& $\begin{array}{l}\text { Labour and within 48 hours } \\
\text { postpartum }\end{array}$ & 20 & 32 & 52 \\
\cline { 2 - 5 } & Post LSCS & 33 & 25 & 58 \\
\cline { 2 - 5 } & Atonic PPH & 7 & 3 & 10 \\
\hline \multirow{3}{*}{ PPH 25 (14\%) } & Traumatic PPH & 6 & 6 & 3 \\
\cline { 2 - 5 } & Coagulopathy & 1 & 2 & 3 \\
\hline APH 11 (6\%) & Abruptio placenta & 2 & 6 & 4 \\
\hline Abortion 4 (2\%) & Placenta previa & 0 & 3 & 2 \\
\hline Molar pregnancy 2 (1\%) & & 2 & 2 & 2 \\
\hline Ectopic pregnancy 2(1\%) & & 1 & 0 & 3 \\
\hline
\end{tabular}

\section{DISCUSSION}

Blood transfusion during or after delivery is serious and sometimes a predictable event. Royal college of Obstetricians and Gynecologists (RCOG) guidelines for BT in Obstetrics aims at appropriate use of blood products that neither compromises the affected women nor exposes her to unnecessary risk. The risk and concern is about infection transmission like HIV, Hepatitis B, Hepatitis C, syphilis, Cytomegalovirus, bacterial contamination and transfusion reactions like fever, urticaria, tachycardia, hypotension and immune haemolysis. ${ }^{3}$

Anaemia was the leading indication for BT in this study. Primigravidas and age group of 22 years and younger 
required the maximum amount of BTs. Maximum number of women entered the pregnancy state from anaemic and nutritionally deficient non pregnant condition. It is recommended that screening for anaemia and prophylactic treatment be started in non-pregnant females under preventive health services. As it is difficult to rule out causes other than iron deficiency anaemia and since anaemia causes are often combined like inadequate dietary intake, parasitic infection or malaria, diagnosis and treatment of other causes of anaemia prevalent in the region should be considered. Meta-analysis of intervention trials suggest that successful prevention of plasmodium falciparum infections in endemic areas reduce the risk of severe maternal anaemia by $38 \% .^{8}$

A reduction in concentration of circulation $\mathrm{Hb}$ is a relatively late development in iron deficiency anaemia and is preceded first by depletion of iron stores, then a reduction in serum iron and finally detectable decrements in the $\mathrm{H}$ level. It has been suggested that women at risk from iron deficiency anaemia can be identified by estimating the serum ferritin concentration in the first trimester. Serum ferritin correlates well with bone marrow stores. Levels below $30 \mathrm{mcg} / \mathrm{l}$ are diagnostic of iron deficiency. WHO recommends that supplements pf $30-60 \mathrm{mg} /$ day of elemental iron be given to those pregnant women who have adequate iron stores and 120-240 $\mathrm{mg} /$ day to those with none.

This study showed that the BTs were more when the interval between the present pregnancy and last delivery was 2 years and less. In an iron deficient women it make take more than a year for $\mathrm{Hb}$ to return to pre pregnancy levels. If she enters into pregnancy again with depleted iron stores then the effects of iron deficiency will develop. This problem can be addressed by setting postnatal clinic anytime from 6 days to 120 days. Comprehensive postnatal clinic can play important role in improving reproduction and child health, in education regarding child spacing, contraception and nutrition. If contraception is accessible and used consistently and correctly, many unwanted pregnancies and morbidity can be decreased significantly. An effort can be made to reduce the number of BTs in Obstetrics by adhering to the guidelines. ${ }^{9}$ It was noted that there was no important physiological impairment at $\mathrm{Hb}$ levels as low as 6-8 $\mathrm{gm} / \mathrm{dl}^{3}$ and more recent studies also have failed to confirm significant association between maternal anaemia and poor foetal outcome. ${ }^{10}$ This study also confirmed still births due to other causes. Naef et al had found that despite a lower haematocrit (mean 0.23), nontransfused patients compared with transfused patients (mean hematocrit 0.28) had similar length of hospital stay, incidence of post-operative infections and wound complications. ${ }^{11}$ It is acceptable to allow patients home with $\mathrm{Hb}$ of $7 \mathrm{gm} / \mathrm{dl}$ (haemotocrit 0.21 ) as long as they are not symptomatic and are receiving adequate oral haematinic therapy.
A study has shown that intravenous iron sucrose on every alternate day for three days increased $\mathrm{Hb}$ levels by 2.4 $\mathrm{gm} / \mathrm{dl}$, a best alternative for treating postpartum anaemia detected of having less than $8 \mathrm{gm} / \mathrm{dl}$ within 48 hours postpartum. ${ }^{12}$ Intravenous iron sucrose definitely allows some blood transfusion to be avoided in postpartum period.

Obstetrician and gynaecologists should address the risk benefit ratio of red cell/ whole blood/component transfusion in a variety of clinical situations in collaboration with anesthetist and formulate strategies to encourage and teach staff the rational use of BT as there is evidence that strategies work in obstetricians. ${ }^{13}$

\section{CONCLUSIONS}

Screening and early treatment of anaemia would avoid the need to transfuse later. Use of alternative treatment like infusion of intravenous iron sucrose in the asymptomatic cases of severe and moderate anaemia definitely reduces the number of BTs especially in the postpartum period. The creation multidisciplinary hospital transfusion committees would enable monitoring, evaluation and control of blood utilisation. Maximum surgical blood ordering schedules guidelines would also reduce unnecessary blood use. Every effort should be made for the rational use of whole blood and component transfusions.

\section{Funding: No funding sources \\ Conflict of interest: None declared}

Ethical approval: The study was approved by the Institutional Ethics Committee

\section{REFERENCES}

1. Svanberg B. Absorption of iron in pregnancy. Act obstetricia Gynaecologica Scandinavica Suppl 1975;48:1-108.

2. Fenton V, Cavill I, Fisher J. Iron stores in Pregnancy. British J Haematol. 1977;37:145-9.

3. Martin C, Didy GA. Blood component therapy. Contemp Obstet. 1994:11-27.

4. World health organisation, Nutritional anaemia, Geneva, WHO. 1972

5. Cooley JR, Kitay D. Hematologic problems in pregnancy $\mathrm{V}$ obstetrics transfusion therapy. Am J obstet Gynecol. 1977;128:476-9.

6. Indications for use of red blood cells, platelets and fresh frozen plasma. Red cross blood bank. Victoria Australia.1993.

7. Sirchia G, GIovanetti AM, Mcclelland DBL, Fracchia ON, editors. Safe and good use of blood in surgery (SANGUIS), European commission,1994.

8. Desai M, ter Kuile FO, Nosten F, McGready R, Asamoa K, Brabin B et al. Epidemiology and burden of malaria in pregnancy. Lancet infect dis. 2007;7:93-104. 
9. Ross A, Makoatzis E. Blood transfusion practice in obstetrics and gynecological anaesthesia. Anaesthesia Intens Care. 1995;23:645.

10. Kilpatrick SJ, Laros Jr R K. Maternal hematological disorders. In: creasy RK, Resnik R, Iams JD, eds, Maternal fetal medicine principles and practice $5^{\text {th }}$ ed. Philadelphia; WB. Saunders Company; 2003:975-1004.

11. Naef RW, Washburne JF, Martin RW, Magann EF, Scanlon PH Jr, Morrison JC. Haemorrhage associated with caesarean delivery; when is transfusion needed. J perinatal. 1995;15(1):32-5.

12. Geeta J, Eremite P, Jhas K. Journal Obstetr Gynaecol India. 2013;63(1);45-8.
13. Morrison JC, Sumrall DD, Chevalier SP, Robinson SV, Morrison FS, Wiser WL. The effect of provider education on blood utilisation practices. Am J obstet Gynecol. 1993;169:1240-5.

Cite this article as: Malipatil P, Malipatil VB. Blood transfusions and its rational use in obstetrics. Int $\mathbf{J}$ Reprod Contracept Obstet Gynecol 2016;5:850-4. 